IRA-International Journal of Management \&

Social Sciences

ISSN 2455-2267; Vol.10, Issue 01 (January 2018)

Pg. no. 36-45

Institute of Research Advances

http://research-advances.org/index.php/RAJMSS

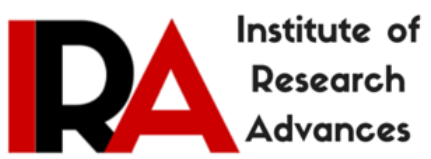

\title{
Role of Economics and Allied Sciences into Information and Computing Fields: Emphasizing Economics \& IT Programs- World and Indian Context
}

\author{
P. K. Paul ${ }^{1 \#}$, A. Bhuimali ${ }^{2}$, P.S. Aithal ${ }^{3}$ \\ ${ }^{1}$ Raiganj University (RGU), West Bengal, India \\ ${ }^{2}$ Vice Chancellor, Raiganj University, West Bengal, India \\ ${ }^{3}$ Vice Chancellor, Srinivas University, Karnataka, India. \\ \# corresponding author. \\ Type of Review: Peer Reviewed. \\ DOI: http://dx.doi.org/10.21013/jmss.v10.n1.p4
}

\section{How to cite this paper:}

Paul, P.K., Bhuimali, A., Aithal, P.S. (2018). Role of Economics and Allied Sciences into Information and Computing Fields: Emphasizing Economics \& IT Programs-World and Indian Context. IRA-International Journal of Management \& Social Sciences (ISSN 2455-2267), 10(1), 36-45. doi:http://dx.doi.org/10.21013/jmss.v10.n1.p4

(C) Institute of Research Advances.

\section{(c) B B-NC}

This work is licensed under a Creative Commons Attribution-Non Commercial 4.0 International License subject to proper citation to the publication source of the work.

Disclaimer: The scholarly papers as reviewed and published by the Institute of Research Advances (IRA) are the views and opinions of their respective authors and are not the views or opinions of the IRA. The IRA disclaims of any harm or loss caused due to the published content to any party.

Institute of Research Advances is an institutional publisher member of Publishers Inter Linking Association Inc. (PILA-CrossRef), USA. The institute is an institutional signatory to the Budapest Open Access Initiative, Hungary advocating the open access of scientific and scholarly knowledge. The Institute is a registered content provider under Open Access Initiative Protocol for Metadata Harvesting (OAI-PMH).

The journal is indexed \& included in WorldCat Discovery Service (USA), CrossRef Metadata Search (USA), WorldCat (USA), OCLC (USA), Open J-Gate (India), EZB (Germany) Scilit (Switzerland), Airiti (China), Bielefeld Academic Search Engine (BASE) of Bielefeld University, Germany, PKP Index of Simon Fraser University, Canada. 


\begin{abstract}
Information Technology is an important and interdisciplinary field of fields. Information Technology is applicable in almost all the areas of Sciences, Arts, and Commerce as well. Even sector wise whether healthcare, government, education, transportation or agriculture-everywhere Information Technology and Computing is required. Hence whether it is a Field or Subject or Sector, Information Technology is very much important and useful. Economics is an important subject for the development; it is more than development today. More importantly, it is valuable to note that Information Technology is not only useful in Economics but also in other contexts viz. Economics also played a great role in the field of Information Technology and Computing. There are many spaces where Economics and Allied Sciences such as Management and Commerce playing an important role. Due to the relationship between Economics and Information Technology, even educational programs worldwide have been developed. The programs are available as Bachelors degree, Masters degree, Doctoral degree etc. In India also in recent past, several improvements were noticed and as a result, educational programs combined with IT and Economics also noted. This paper is conceptual in nature and deals with the analysis and discussion on the application of Economics and allied subjects in the field of Information Technology and Computing. Moreover, the paper also discusses the educational programs available in India combined with IT and Economics.
\end{abstract}

Keywords: Information Technology, Economics, Development, Information Science, Research, Knowledge Economy, IT, Economics, Indian Universities

\title{
Introduction
}

Information is most important and valuable tool for the development and in many circumstances, it is basic for modernization, globalization etc. Data, Information, and Knowledge are very much close and related to each other [1], [7]. For the development of a society, economy, and civilization these are most important and valuable. Once the concept of Information and its role enhanced, the existing society has been shifted from Industrial Society to Information Society. Though, before that (i.e. Industrial Society) another concept of society has emerged that is called Agriculture Society [2], [3], [11].

Though, the advancement of Information and Communication Technologies lead the concept of Knowledge Society as well. Hence in many senses, such kind of Economy is also very much depended on Knowledge Economy [4], [6], [11]. It is the fact that Information Technology and allied fields are very much important and responsible for the information activities viz.

$\begin{array}{ll}- & \text { Collection } \\ - & \text { Selection } \\ \text { - } & \text { Organization } \\ \text { - } & \text { Processing } \\ \text { - } & \text { Management and } \\ -\quad & \text { Dissemination. }\end{array}$

Hence indirectly Information Technology and Computing play a vital role regarding the development of economy with the core concentration of information and knowledge dissemination [5], [8], [9]. Thus there is a great relationship between Information Technology and Computing with Economics. As far as allied domains of Economics are concerned few important are Management, Commerce, and Business Studies-and all these play a tremendous relationship in Information Technology as well. A common relationship with Economics and IT is the application of Computers and Information Technology in Economics and Allied Sciences as a whole [10], [11], [12]. Moreover, Economics and Allied Sciences are also applicable in the areas or IT organization and industries as well in different context. The relationship of Economics and Information Technology even these days is available as an educational programs leading to Bachelors Degree and Masters Degree. Although it is important to note that the research work/ programs leading to Doctoral Degree already started before Bachelors and Masters Degrees in some of the universities and the trend of undergraduate and postgraduate programs in the fields are rising in recent past [12], [14], [16]. 


\section{Objective and Aim}

The following are few aim and objectives in this regard for the said paper entitled as 'Role of Economics and Allied Sciences into Information and Computing fields: Emphasizing Economics \& IT Programs-World and Indian Context' in a brief manner-

- To learn basics of Information Technology and its characteristics with reference to its components in brief.

- To know about the application of Information Technology in different fields in a brief manner.

- To dig out emerging aspects of Economics with reference to its applications in Information Technology and Computing in detail.

- To learn about the emerging concept created with IT and Economics concentration viz. Knowledge Economics and IT Economics.

- To learn about the detailed overview of private universities available in India.

- To know about the IT and Economics related educational programs in the worldwide for more clarification.

- To get a detailed overview of IT and Economics related programs started in Indian Universities.

- To learn about the basics of curricula of BSc-Computational Economics \& Analytics offered in Indian universities with special reference to the private universities.

\section{Methodologies Adopted}

The present work is conceptual in nature and deals with various educational methods due to its nature. First of all review of the literature has been undertaken to learn about the basics of information technology including its nature and characteristics. Moreover basics of economics and allied affairs also gathered from the review of the literature. For the review, many journals, books etc are referred, importantly web review has been undertaken to learn basics of Indian private universities and more on the availability of economics and IT integrated programs in India as well. Significantly UGC's (Government of India) website considered as vital one to get information of private universities in India and each of the universities were searched, analyzed and reported as a part of this research work.

\section{Economics and Allied Fields}

Economics is today treated as one of the important and valuable subjects, and considered as a field of fields [13], [15], [17]. Economics in-generally classified into Micro Economics and Macro Economics. Though in another context it is classified into General Economics (may be considered as Theory focus) and Applied Economics. Based on importance, role, interaction, and integration of Economics with other subjects several other merging domains have been created and among these few important are-

- Health Economics

- Business Economics

- Agricultural Economics

- Environmental Economics etc.

The Integration of Economics and Allied Sciences has been created several other emerging areas and fields; details of such facets have been depicted in the next section.

\section{IT Vis-à-Vis Economics}

The application of Information Technology and Computing has created a new age in this interdisciplinary science. The integration of Economics and Allied Sciences (Management Science, Commerce, and Business Studies) with Information Technology and Computing created several new fields and concept as well-

- Information Economics.

- Knowledge Economics.

- IT Economics.

- Internet Economics etc.

It is important to note that the integration and relationship also resulted in few other emerging concepts in recent past viz. virtual marketplaces, virtual organizations, business clusters, human capital, knowledge flows and so on. 
The general economy shifted to the knowledge economy with the help of different facets and tools and out of which Information Technology will play a vital role.

Hence the creation and integration of IT and Economics not only bring us knowledge economy but also it is dedicated to the generation of tangible and intangible values. Technologies i.e. IT and Computing is playing a great role in the incorporation of human knowledge into machines [15], [18], [19]. Ultimately such knowledge is also used by decision support systems (DSS) in various fields and will ultimately help in the generation of economic value. Ultimately to see such importance and values organizations and institutions are not only moving towards economical tools powered by the computing but as a whole society and economy lie on Information Technology and Computing [12], [21].

\section{Economics in IT and Computing Programs Worldwide}

Worldwide due to the importance of Information Technology with Economics and other areas many Research Centers and groups have already been created in the academic institutions and universities. The rapid interaction and dependencies in this segment have been created several degrees in leading universities and in developed countries [18], [20], [22]. Among the programs, few important are BSc in Computer Science \& Economics. Though, in some universities, the nomenclatures are also IT Economics, Information Technology and Economics etc. Most of the programs in the field are offered from the European Countries. Table: 1 depicts few universities offering such programs with Degrees and subject/ nomenclature offered.

Table: 1-A Snapshot of IT and Computing Allied Programs, internationally

\begin{tabular}{|c|c|c|c|}
\hline Sl. No. & Some Econ & elated IT and Compu & ograms Internationally \\
\hline & Universities & Place & Programs \\
\hline 1 & $\begin{array}{l}\text { University of St. } \\
\text { Andrews }\end{array}$ & St. Andrews, Scotland & $\begin{array}{c}\text { BSc (Hons) } \\
\text { Computer Science \& Economics }\end{array}$ \\
\hline 2 & University of Leiden & Leiden, Netherlands & $\begin{array}{c}\text { BSc in } \\
\text { Computer Science \& Economics }\end{array}$ \\
\hline 3 & Bocconi University & Milan, Italy & $\begin{array}{c}\text { BSc in Economics, Management and } \\
\text { Computer Science }\end{array}$ \\
\hline 4 & Brown University & Rhode, US & $\begin{array}{c}\text { BSc (Joint) } \\
\text { Computer Science-Economics }\end{array}$ \\
\hline 5 & Brock University & Ontario, Canada & $\begin{array}{c}\text { BSc in } \\
\text { Computer Science \& Economics }\end{array}$ \\
\hline 6 & Aberystwyth University & Aberystwyth, Wales & $\begin{array}{c}\text { BSc } \\
\text { Business Economics with Computer } \\
\text { Science }\end{array}$ \\
\hline
\end{tabular}

It is worthy to note that while most of the universities offer integrated nomenclature as Economics and Information Technology but few universities offer Double Degree programs viz. BSc Economics with BSc Information Technology, for example, Brown University, Rhode, United States. These programs have been designed with the focused contents like applications of Economics in the field of Information Technology, Application of IT and Computing in Economics and allied fields, aspects like E-Governance, Project Management, IT Business Management, Internet Economics, and Developing IT Projects etc are very much important contents. However few universities have been started Masters Programs with a concentration in Management Science and Economics and Allied Science. In this regard, Table: 2 provides a detailed picture of programs offered by the international universities. 
Table: 2-Economics and IT Allied Masters Degrees worldwide.

\begin{tabular}{|c|c|c|c|}
\hline $\begin{array}{c}\text { SI. } \\
\text { No. }\end{array}$ & \multicolumn{2}{|c|}{ Some Economics related IT and Computing Masters Programs Internationally } \\
\hline \multirow{2}{*}{ Universities } & Place & Programs \\
\hline 1 & $\begin{array}{c}\text { The London School of } \\
\text { Economics }\end{array}$ & London & $\begin{array}{c}\text { MSc Management of Information } \\
\text { Systems and Digital Innovations }\end{array}$ \\
\hline 2 & City University of London & London & $\begin{array}{c}\text { MSc- Information Systems and } \\
\text { Technology } \\
\text { (Economics Concentration) }\end{array}$ \\
\hline 3 & $\begin{array}{c}\text { ETH Swish Federal Institute of } \\
\text { Technology, Zurich }\end{array}$ & Zurich, Switzerland & $\begin{array}{c}\text { MS-Management, Technology and } \\
\text { Economics }\end{array}$ \\
\hline & Bocconi University & Milan, Italy & $\begin{array}{c}\text { MSc in Economics and Management } \\
\text { of Innovation and Technology }\end{array}$ \\
\hline
\end{tabular}

It is worthy to note that many universities around the world in this context have been started programs concentrated with technology management as well. The world leading school The London School of Economics as well started an MSc degree in the field. And the program is called as MSc Management of Information Systems and Digital Innovations. The program is truly interdisciplinary in nature and blended with the Economics, Managerial Sciences with Technologies (more than IT).

\section{Economics and IT integrated Programs in India: Emphasizing Private Universities}

The importance of IT and Economics with allied subjects and vice versa lead the educational and academic programs that already learned. As far as India is concerned the higher educational institutes (HEIs) are classified into following viz.

- Central Universities.

- State Universities.

- $\quad$ Private Universities.

- $\quad$ Deemed Universities.

India moreover holds the highest number of HEIs that is about 40000+ and among these degree awarding bodies are found to be more than eight hundred (800). The present study has been aimed with the intention of gathering knowledge regarding availability of IT and Economics blended programs in Indian Universities [12], [13].

Table: 3-Nation Wide Private Universities at a glance

\begin{tabular}{|c|l|c|}
\hline Serial No. & \multicolumn{1}{|c|}{ States } & No. of Universities \\
\hline 1 & Arunachal Pradesh & 7 \\
\hline 2 & Assam & 5 \\
\hline 3 & Bihar & 2 \\
\hline 4 & Chhattisgarh & 9 \\
\hline 5 & Gujarat & 30 \\
\hline 6 & Haryana & 20 \\
\hline 7 & Himachal Pradesh & 17 \\
\hline 8 & Jharkhand & 7 \\
\hline 9 & Karnataka & 8 \\
\hline 10 & Meghalaya & 14 \\
\hline 11 & Mizoram & 24 \\
\hline 12 & Madhya Pradesh & \\
\hline
\end{tabular}




\begin{tabular}{|c|l|c|}
\hline 13 & Maharashtra & 9 \\
\hline 14 & Manipur & 1 \\
\hline 15 & Nagaland & 3 \\
\hline 16 & Odisha & 4 \\
\hline 17 & Punjab & 15 \\
\hline 18 & Rajasthan & 46 \\
\hline 19 & Sikkim & 5 \\
\hline 20 & Tripura & 1 \\
\hline 21 & Uttar Pradesh & 29 \\
\hline 22 & Uttrakhand & 13 \\
\hline 23 & West Bengal & $\mathbf{2 7 9}$ \\
\hline \multicolumn{2}{|}{ Trand } & \\
\hline
\end{tabular}

It has been noted that as per the study no universities (from central, state and deemed) are offering degree programs in the targeted fields except private universities. It is worthy to mention that India received a good number of private universities in the last decade and today the number touches 279. Among the states, Rajasthan holds the highest position in the number of private universities. Today there are 46 universities in the State, while Gujarat holds second position and Madhya Pradesh holds third position with the number of universities 30 and 29 respectively.

It is worthy to note that among the 279 private universities in India two universities are offering Economics and IT concentrated academic programs leading to BS degree. Significantly one is from Karnataka and another is from Uttar Pradesh. The details on this, including universities and program nomenclatures, have been listed in Table: 4 .

Table: 4-Indian Universities offering Economics concentrated IT and Computing Programs in India

\begin{tabular}{|c|c|c|c|}
\hline SI. No. & \multicolumn{2}{|c|}{ Economics and IT Integrated Programs } \\
\hline & Universities & Place & Programs \\
\hline 1 & Reva University & Bangalore & $\begin{array}{c}\text { BS- Computational Mathematics } \\
\& \text { Economics }\end{array}$ \\
\hline 2 & $\begin{array}{c}\text { Maharishi University of Information } \\
\text { Technology }\end{array}$ & Lucknow & $\begin{array}{c}\text { BSc-Computational Economics \& } \\
\text { Analytics }\end{array}$ \\
\hline
\end{tabular}

It is important to note that while most of the programs (listed in Table: 1) available internationally are deals with application of Economics and Management Sciences (including commerce and business) in the areas of IT \& Computing and IT in Economics related affairs (such as statistical analysis, software applications etc); but 2 Indian Private Universities mainly concentrated the program on the second theme more clearly the programs are designed for acquiring knowledge in Economics and mainly in the following -

- $\quad$ Quantitative analysis

- $\quad$ Economic research and analysis

- Mathematical and statistical techniques

- $\quad$ Financial models and computational skills etc.

Importantly the programs focused on mathematics, statistics as well as computing related models in the economics and also in financial market analysis etc. The program lies in strong mathematical and computational skills including Econometrics, Game Theory and so on. The program offered by the REVA University is with the nomenclature of Bachelor of Science (BS) in Computational Mathematics and Economics and thus the program leads the career opportunities in diverse fields mentioned bellow but not limited to the-

- $\quad$ Financial and commercial institutions 
- $\quad$ Banks and Corporate Bodies

- Investment corporation and agencies

- $\quad$ Insurance companies with the consulting firms [24]

Moreover, the program has been designed for better and healthy economic research and analysis. And later on, students can go for the pursuing higher studies and research in different areas such as Mathematics, Economics. The program seeks candidates from the Science stream $(10+2)$ candidates. It is a minimum 8 Semester program. Though another program with the nomenclature of BSc-Computational Economics \& Analytics offered at the Maharishi University of Information Technology also more or less similar program but here BSc award is proposed instead of BS. Moreover, it is a Three-year program and the program in respect of Computing and IT has been constituted with some of the elements such as-

- C Programming Language

- Data Analysis using Excel

- $\quad$ Statistical Analysis using SPSS/ STATA

- $\quad$ E-Commerce and Digital Analytics

- $\quad$ Financial Computing

- $\quad$ Basics of DBMS/ Big Data

- Data handling in Hadoop

- Business Analytics Projects etc

Though in Economics segment as well apart from general areas of economics few other areas viz. Management Science etc are included [25]. A detailed curriculum (to clear the whole field) of Maharishi University of Information Technology, Lucknow has been depicted in Table: 5.

Table: 5- BSc program in Computational Economics \& Analytics at MUIT, Uttar Pradesh [25]

\begin{tabular}{|ll|}
\hline \multicolumn{2}{|c|}{ Maharishi University of Information Technology } \\
\hline \multicolumn{1}{|c|}{ Semester I } & \multicolumn{1}{c|}{ Semester II } \\
Core & Core \\
Introductory Microeconomics & Econometrics Fundamentals \\
Introductory Macroeconomics & Macroeconomics \& Finance \\
Fundamentals of Business \& Accounting & Data Analysis using Advanced Excel \\
Probability and Statistics & Fundamentals of Programming using C \\
Data Summarisations using Excel & Electives [any two] \\
Electives [any one] & Statistical Analysis using SPSS or STATA \\
English Language using Essentials & Effective Written Communication \\
Introduction to communication skills & Problem Solving and Creative Thinking \\
\hline
\end{tabular}




\begin{tabular}{|c|c|}
\hline \multirow[t]{3}{*}{ Semester III } & Semester IV \\
\hline & Core \\
\hline & E - commerce and Digital Analytics \\
\hline Financial Computing & Financial Markets and Products \\
\hline Marketing Management & Introduction to Database Management \\
\hline Mathematics for Business Economics & Systems / Big Data / Data Science \\
\hline Econometrics II & Electives [any two] \\
\hline Electives [any one] & Entrepreneurship and Family Business \\
\hline \multirow{2}{*}{ Statistical Analysis using SAS - BASE } & Foundations of HR \\
\hline & Statistical Analysis using SAS - Intermediate \\
\hline Statistical Analysis using R - Basic & Statistical Analysis using R - Intermediate \\
\hline Semester V & Semester VI \\
\hline \multicolumn{2}{|l|}{ Core } \\
\hline Basics of Modeling and Simulation & Business Analytics Live Project \\
\hline Unstructured Data Handling in Hadloop & Internship \\
\hline \multicolumn{2}{|l|}{ Basics of Text Mining Algorithms } \\
\hline \multicolumn{2}{|l|}{ Electives [any one] } \\
\hline \multicolumn{2}{|l|}{ Stock / Investment Analysis } \\
\hline \multicolumn{2}{|l|}{ Financial Engineering } \\
\hline \multicolumn{2}{|l|}{ Receptive and Expressive } \\
\hline \multicolumn{2}{|l|}{ Communication Skills } \\
\hline Group Dynamics and Team Building & \\
\hline
\end{tabular}

Economics as Eligibility Criteria for Computing Degree Programs: Private University Context

Initially, the Computing fields gained as a different and distinguish area and later a study area by the researchers from the Mathematics and allied branch of study. Due to need and relationship of Mathematics still, it becomes important eligibility criteria for admission into the Computing and IT Programs. Hence apart from Computing/IT still Mathematics becomes a relevant subject for admission into Computing and IT programs in India leading to BSc, MSc, BCA, MCA programs. MCA Program has been started and designed for the opportunity to enter into the IT profession and thus the normal eligibility for the admission of MCA is Mathematics at 10+2 or Bachelors degree level. While general MSc in IT and Computing field normally open for Graduate in the fields or at-least relevant field and here Mathematics is considered as a relevant field of study. Though this study is concentrated on private universities and apart from economics concentration in IT programs, which already studied previously another significant concern is the eligibility of the MCA/ MSc in the Computing (and Advance areas) with Economics as an alternative subject of Mathematics. The Table: 6 in this regard offered a detailed picture. 
Table: 6- Economics the Gateway to Masters in Computing related programs in Private Universities

\begin{tabular}{c|c|c|c|} 
S. & \multicolumn{2}{|c|}{ Economics as an eligibility for Computing \& IT Programs } \\
No. & Universities & Place & Programs \& Eligibility \\
\hline 1 & Ganpat University & Mehsana & $\begin{array}{c}\text { MSc-IT (Cyber Security) } \\
\text { (Relevant Paper including } \\
\text { Economics) }\end{array}$ \\
\hline 3 & D.A.V. University & Jalandhar & $\begin{array}{c}\text { MCA } \\
\text { (Relevant Degree including BSc- } \\
\text { Economics } \\
\text { or Paper) }\end{array}$ \\
\hline 4 & $\begin{array}{c}\text { Maharishi University of Information } \\
\text { Technology }\end{array}$ & Phagwara & $\begin{array}{c}\text { MSc-Software Development } \\
\text { (Related \& Relevant Degree } \\
\text { including Economics) }\end{array}$ \\
\hline & Lucknow & $\begin{array}{c}\text { MSc-Analytics \& Big Data } \\
\text { (Related \& Relevant Degree } \\
\text { including Economics) }\end{array}$ \\
\hline
\end{tabular}

Findings

- Economics is a most interdisciplinary field of study these days and the field is gaining the reputation in different academic attributes viz. Health Economics, Business Economics, and Environmental Economics including already popularized Agricultural Economics.

- A Common perception (regarding the relationship of IT \& Economics) is that IT and Computing is only applicable in Economics and allied field of study, but it is important concern today that Economics and allied subjects play a great role for many IT affairs viz. E-Governance, Project Management, IT Business Management, Internet Economics, and Developing IT Projects etc.

- Worldwide many universities have started integrated programs on Information Technology and Computing with Economics. Most of these are with BSc and MSc nomenclature. The concentrations of such programs are normally conceptual, managerial in nature in respect of IT and Computing.

- In India also the programs on IT and Economics concentration being noticed during this study and among $800+$ Indian Universities only private universities bagged the program offering.

- The IT and Economics integrated programs in India is only available in 2 Private Universities with Bachelors Degree (i.e. BSc).

\section{Conclusion}

The Developments in today's age purely depends on Economy and here Economics play a vital role. Economics deals with several financial affairs and Managerial affairs of any system. Simultaneously Information Technology also plays a great role in respect of development and it is also applicable in different subjects and sectors. Initially, application of computing tools and techniques in different areas of economics were considered as most vital and important. But later on, the significant role of Economics in the field of Information Technology and Computing also been noticed and considered as most vital. E-Governance, Project Management, IT Business Management, Internet Economics, and Developing IT Projects are the key concern for the development of IT affairs and improvement of IT services and sectors. Due to its significance, internationally many universities have started the program on this emerging area in leading universities. India is a developing nation and thus in recent past, significant development has been noticed in a different segment. In respect of Information Technology as well a valuable growth has been noticed. The development of IT as a subject also a significant move and thus as a result, several new universities were established in recent past. Moreover, the IT and Economics integrated academic programs leading to Bachelors also noticed. It is worthy to note that the relationship with Economics and Information Technology also studied in respect of eligibility criteria in different Masters programs in the field of 
Computing and IT. Hence in future, more development in respect of Economics and IT are waiting for and thus universities need to involve in designing and developing programs in this space.

\section{References}

[1] Agarwal, P. (2007). Higher education in India: Growth, concerns and change agenda. Higher Education Quarterly, 61(2), 197-207.

[2] Black, S. E., \& Lynch, L. M. (2001). How to compete: the impact of workplace practices and information technology on productivity. Review of Economics and statistics, 83(3), 434-445.

[3] Brynjolfsson, E., \& Hitt, L. M. (2000). Beyond computation: Information technology, organizational transformation and business performance. Journal of Economic perspectives, 14(4), 23-48.

[4] Clemons, E. K., \& Row, M. C. (1992). Information technology and industrial cooperation: the changing economics of coordination and ownership. Journal of Management Information Systems, 9(2), 9-28.Desai, S., \& Kulkarni, V. (2008). Changing educational inequalities in India in the context of affirmative action. Demography, 45(2), 245-270.

[5] Gereffi, G., Wadhwa, V., Rissing, B., \& Ong, R. (2008). Getting the numbers right: International engineering education in the United States, China, and India. Journal of Engineering Education, 97(1), 13-25.

[6] Gupta, D., \& Gupta, N. (2012). Higher education in India: structure, statistics and challenges. Journal of education and Practice, 3(2), 17-24.

[7] Kapur, D., \& Mehta, P. B. (2004). Indian higher education reform: From half-baked socialism to half-baked capitalism. Center for international development working paper, 103.

[8] McKnight, L. W., \& Bailey, J. P. (1997). Internet economics: When constituencies collide in cyberspace. IEEE Internet Computing, 1(6), 30-37.

[9] Ma, R. T., Chiu, D. M., Lui, J., Misra, V., \& Rubenstein, D. (2010). Internet Economics: The use of Shapley value for ISP settlement. IEEE/ACM Transactions on Networking (TON), 18(3), 775-787.

[10] Nambissan, G. B., \& Rao, S. (Eds.). (2013). Sociology of education in India: Changing contours and emerging concerns. New Delhi: Oxford University Press.

[11] Paul, P. K., Kumar, A., Poovammal, E., \& Dangwal, K. L. (2014). Information Science: A Potential interdisciplinary field with Historical Perspectives and Future Potentials. Educational Quest, 5(3), 211-215.

[12] Paul, Prantosh and Bhuimali, A. and Aithal, P. S. (2017), Indian Higher Education: With Slant to Information Technology - a Fundamental Overview. International Journal on Recent Researches In Science, Engineering \& Technology, 5(11), 31-50.

[13] Paul, P. K., Aithal, P. S. and Bhuimali, A., (2017). Computing \& Allied Engineering Domain in India with Reference to Private Universities: A Case Study of Bachelors Programs, International Journal on Recent Researches In Science, Engineering \& Technology, 5(11), 51-63.

[14] Sharma, Jagdish (2006), "Diaspora: History of and Global Distribution", Encyclopedia of India (vol. 1) edited by Stanley Wolpert, pp. 331-336, Thomson Gale, ISBN 0-684-31350-2.

[15] Sharma, Shalendra D. (2006), "Globalization", Encyclopedia of India (vol. 2) edited by Stanley Wolpert, pp. 146-149, Thomson Gale, ISBN 0-684-31351-0.

[16] Singal, N. (2006). Inclusive education in India: International concept, national interpretation. International journal of disability, development and education, 53(3), 351-369.

[17] Sood, R., \& Adkoli, B. V. (2000). Medical education in India-problems and prospects. J Indian Acad Clin Med, 1(3), 210-212.

[18] Sohani, N., \& Sohani, N. (2012). Developing interpretive structural model for quality framework in higher education: Indian context. Journal of Engineering, Science \& Management Education, 5(2), 495-501.

[19] Supe, A., \& Burdick, W. P. (2006). Challenges and issues in medical education in India. Academic Medicine, 81(12), 1076-1080.

[20] Tate, D. S., \& Schwartz, C. L. (1993). Increasing the retention of American Indian students in professional programs in higher education. Journal of American Indian Education, 21-31.

[21] Tayade, M. C., \& Kulkarni, N. B. (2011). The Interface of technology and medical education in india: current trends and scope. Indian Journal of Basic \& Applied Medical Research, 1(1), 8-12.

[22] Tijerina, K. H., \& Biemer, P. P. (1988). The Dance of Indian Higher Education: One Step forward, Two Steps back. Educational Record, 68(4), 86-91.

[23] Umashankar, V., \& Dutta, K. (2007). Balanced scorecards in managing higher education institutions: an Indian perspective. International Journal of Educational Management, 21(1), 54-67.

Web Sourses Used

[24] http://reva.edu.in/sost/bs-in-computational-mathematics-and-economics (Accessed on 11-11-17).

[25] http://muitnoida.edu.in/school-data-science-brochure.pdf (Accessed on 11-11-17). 